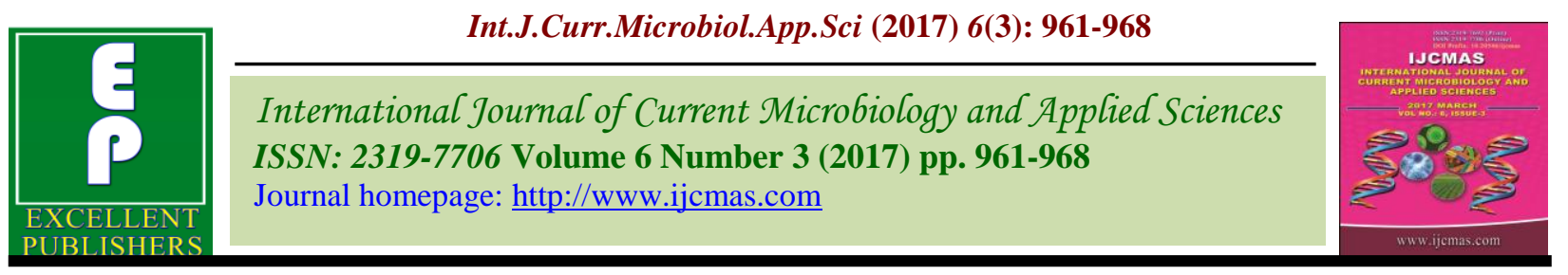

Original Research Article

https://doi.org/10.20546/ijcmas.2017.603.114

\title{
Evaluation of Soil Fertility Status from Kanchanpur District, Far-Western Development Region of Nepal
}

\author{
A.I. Khan ${ }^{1}$, N.L. Uranw ${ }^{2}$, R.N. Yadav ${ }^{3}$, Y.V. Singh ${ }^{4}$, Durgawati Patel ${ }^{3}$ and Renu Yadav \\ ${ }^{1}$ International Rice Research Institute, Kanchanpur, Nepal \\ ${ }^{2}$ Regional Soil Testing Laboratory, Kanchanpur, Nepal \\ ${ }^{3}$ Department of Mycology and Plant Pathology, Institute of Agricultural Sciences, Banaras \\ Hindu University, Varanasi, 221005, India \\ ${ }^{4}$ Department of Soil Science and Agricultural Chemistry, Institute of Agricultural Sciences, \\ Banaras Hindu University, Varanasi 221005, India \\ *Corresponding author
}

\section{A B S T R A C T}

Soil fertility evaluation of an Agricultural field is an important aspect in context of sustainable agricultural production. The macro and micro nutrients govern fertility of soils and control the growth yield of crops. The main aim of this study was to evaluate soil

Keywords fertility status from Kanchanpur district of Nepal. Sixty seven surface soil $(0.5-15 \mathrm{~cm})$ samples were analyzed for various soil fertility parameters like $\mathrm{pH}, \mathrm{EC}$, organic matter,

Organic matter, Bio-fertilizer, Bulk density, Awareness camp, etc. available $\mathrm{N}, \mathrm{P}, \mathrm{K}$, bulk density, particle density and porosity by standard procedure. The $\mathrm{pH}$ value ranged from 5.5-6.8 reflecting slightly acidic to neutral nature of soils. E.C. ranges between $0.16-0.40 \mathrm{dSm}^{-1}$. Organic carbon ranges from $0.96-4.20 \%$. Hundred percent samples showing high organic carbon status, $55.22 \%$ medium and $54.88 \%$ high status in available $\mathrm{N}$ and most of the soils sample has high status in $\mathrm{P}, 88.05 \%$ samples are high in phosphorous, while $34.32 \%$ samples are low, $58.20 \%$ medium and $7.46 \%$ high in available K. Proper agriculture practices, intensive farming, forest biomass are responsible for soil fertility of soil. Bulk density ranges from 1.31 to $1.40 \mathrm{mg} \mathrm{m}^{-3}$, particle density ranges from 2.25 to $2.40 \mathrm{mg} \mathrm{m}^{-3}$ porosity ranges from 55.1 to $60.8 \%$. Soil samples are good in status, However to continue fertility status or to overcome from the adverse effect, complementary use of bio-fertilizers, organic manures in appropriate combination of chemical fertilizers were suggested. Awareness camp, rallies, and training program can be arrange for farmer regarding the benefits of balanced use of fertilizers.

\section{Introduction}

Soil plays a major role in determining the sustainable productivity of an agroecosystem. The sustainable productivity of a soil mainly depends upon its ability to supply essential nutrients to the growing plants. Uptake of micronutrients is affected by the major nutrients due to either negative or positive interaction (Fageria, 2001). The degradation of soil has started occurring both due to natural and human induced factors which in turn affecting the productivity. As human population continue to increase, human disturbance of the earth's ecosystem to produce food and fiber will place greater demand on soil to supply essential nutrients. The soils native ability to supply sufficient 
nutrients has decreased with higher plant productivity level associated with increased human demand for food. Therefore one of the greatest challenges today is to develop and implement soil, crop and nutrients management technologies that enhance the plant productivity and quality of soil, water and air. The evaluation of soil fertility includes the measurement of available plant nutrients and estimation of capacity of soil to maintain a continuous supply of plant nutrients for a crop. The availability of nutrients depends on various factors such as type of soil, nature of irrigation facilities, $\mathrm{pH}$ and organic matter content. According to (Lal and Singh, 1998), soil quality degradation process with reference to productivity or fertility encompasses physical chemical and biological degradation process. This is prerequisite for determining appropriate conservation activities in monitoring our natural resource base. The present study was undertaken to know the macro nutrient status of soils of Kanchanpur district, Nepal and an attempt was also made to correlate macro nutrients content of the soils with other soil properties. Present investigation was useful in judging the deficiency of various element and thereby use of fertilizers depending on their status. The present study was conducted for covering study of the status of macronutrient and their correlation with physico-chemical properties in the soils of Kanchanpur district, Nepal.

\section{Materials and Methods}

\section{Study area}

Kanchanpur, district, Far-Western Development Region of Nepal, Co-ordinates of the location is $28.8372^{\circ} \mathrm{N}, 80.3213^{\circ} \mathrm{E}$ and elevation ranges lower tropical below 300 meters and upper tropical 300-1000meters. About half of the land of this district is cultivable and near about $1 / 3$ is forest. Soils of this district are mostly clay loam and light textured to medium textured. Farmers of this district are progressive and creative. Farmers of this district are grower of about all type of crops like cereals, pulses, vegetable and flower too. Farmers become aware about their soil health.

\section{Soil sampling}

Selected 67 surface soil samples $(0.5-15 \mathrm{~cm})$ were collected in butter paper bag as per the standard procedure. Quartering technique was used for preparation of soil sample. The samples were dried in air and passed through $2 \mathrm{~mm}$ sieve and stored in dry clean cloth bag. The soil $\mathrm{pH}$ and EC were determined from the saturation extract (1:2.5 soil water ratio) of soils (Jackson, 1973). The soil samples were analyzed for organic carbon (Walkley and Black, 1934), available N (Subbiah and Asija, 1956), available P (Olsen et al., 1954), and available K (Hanyway and Heidal, 1952). Bulk Density was determined by clod method (Black, 1965).

\section{Statistical analysis}

The relationship between different soil characteristics and micronutrient contents in soils and plants were determined using correlation coefficients:

$r=\sqrt{\frac{S P(x y)}{S S(x)_{y} S S(y)}}$

Where:

$\mathrm{r}=$ Correlation coefficient

SP $(x y)=$ Sum product of $x, y$ variables

SS $(x)=$ Sum of square of $x$ variable

SS $(y)=$ Sum of square of y variable

\section{Results and Discussion}

\section{Physicochemical properties of soil}

The data on $\mathrm{pH}, \mathrm{EC}, \mathrm{B} . \mathrm{D}, \mathrm{P} . \mathrm{D}$, porosity and 
organic carbon are presented in tables 1 and 2 . The data shows that the $\mathrm{pH}$ of these soils was ranged from 5.5- 6.8 with average value of 7.1 the lowest $\mathrm{pH}$ was recorded in sample $\mathrm{S}$ 5 while highest was observed in many samples.

\section{Status of available $\mathbf{N}, \mathbf{P}$ and $\mathrm{K}$ in soil}

The status of $\mathrm{N}, \mathrm{P}$ and $\mathrm{K}$ has been shown in tables 3 and 4 and its subparts. Table 5 shows limits for soil test values used in India Muhr et al., Available nitrogen content of these soils were ranged from 290 to $1218 \mathrm{~kg} \mathrm{ha}^{-1}$ with a mean value of $580 \mathrm{~kg} \mathrm{ha}^{-1}$. S.D. value of 40.12 and C.V. value of $23.80 \%$. Out of 67 soil samples collected from Kanchanpur, district, Nepal. 54.88\% soil samples were found high and $55.22 \%$ soil samples were found in medium range. Climate has a major impact on availability of nitrogen, maximum soil samples were found in low category it may be due to uncertain rainfall. Similar result was observed by Verma et al., that the available nitrogen content in soils of Arid Tract of Punjab, India.

The available phosphorous content in these soils were varied from 18.5 to $90.50 \mathrm{~kg} \mathrm{ha}^{-1}$ with a mean value of $35.74 \mathrm{~kg} \mathrm{ha}^{-1}$.S.D value of 1.33 and C.V. value of $25.10 \%$. Out of 67 soil samples collected $11.94 \%$ soil samples were found medium, $88.05 \%$ soil samples found high in P content.

Table.1 Description of sampling site of Kanchanpur, district, Nepal

\begin{tabular}{|c|c|c|c|c|c|c|c|c|c|c|}
\hline S.N & Cropping System & $\mathrm{pH}$ & $\begin{array}{l}\text { E.C. } \\
\text { (dSm-1) }\end{array}$ & $\begin{array}{l}\text { O.C. } \\
\%\end{array}$ & $\begin{array}{l}\text { Av. N } \\
\text { (kg/ha) }\end{array}$ & $\begin{array}{l}\text { Av. P } \\
(\mathrm{kg} / \mathrm{ha})\end{array}$ & $\begin{array}{l}\text { Av. K } \\
\text { (kg/h) }\end{array}$ & $\begin{array}{l}\mathrm{BD} \\
\left(\mathrm{gmcm}^{-3}\right)\end{array}$ & $\begin{array}{l}\mathrm{PD} \\
\left(\mathrm{gmcm}^{-3}\right)\end{array}$ & $\begin{array}{l}\text { Porosity } \\
(\%)\end{array}$ \\
\hline 1 & Rice- Wheat & 6.6 & 0.17 & 2.5 & 750.00 & 32.21 & 280.20 & 1.35 & 2.25 & 60.8 \\
\hline 2 & Rice- Wheat & 6.7 & 0.18 & 1.8 & 543.00 & 35.32 & 285.36 & 1.33 & 2.27 & 58.1 \\
\hline 3 & Rice- Wheat & 6.6 & 0.16 & 3.20 & 970.00 & 41.12 & 140.23 & 1.34 & 2.28 & 58.2 \\
\hline 4 & Rice- Wheat-Rice & 6.6 & 0.20 & 1.27 & 384.00 & 32.20 & 220.00 & 1.31 & 2.40 & 54.2 \\
\hline 5 & Rice- Wheat & 5.5 & 0.19 & 4.10 & 1218.00 & 51.50 & 190.00 & 1.31 & 2.29 & 57.3 \\
\hline 6 & Rice- Wheat-Rice & 6.5 & 0.18 & 2.11 & 637.00 & 56.20 & 231.00 & 1.32 & 2.34 & 56.5 \\
\hline 7 & Sugarcane & 6.5 & 0.17 & 2.27 & 684.00 & 51.12 & 210.03 & 1.35 & 2.38 & 56.7 \\
\hline 8 & Rice- Wheat & 6.6 & 0.19 & 3.20 & 960.00 & 90.50 & 112.32 & 1.31 & 2.34 & 55.9 \\
\hline 9 & Sugarcane & 6.5 & 0.18 & 1.27 & 384.00 & 62.30 & 356.32 & 1.40 & 2.41 & 58.0 \\
\hline 10 & Rice- Wheat & 6.5 & 0.17 & 1.38 & 412.00 & 61.21 & 203.32 & 1.37 & 2.25 & 60.8 \\
\hline 11 & Sugarcane & 6.5 & 0.17 & 1.01 & 305.00 & 31.14 & 204.32 & 1.35 & 2.34 & 57.6 \\
\hline 12 & Rice- Wheat & 6.5 & 0.18 & 1.57 & 466.00 & 32.21 & 291.01 & 1.38 & 2.36 & 58.4 \\
\hline 13 & Rice- Wheat & 6.4 & 0.17 & 1.91 & 590.00 & 42.23 & 295.02 & 1.34 & 2.37 & 56.5 \\
\hline 14 & Rice- Wheat & 6.5 & 0.16 & 1.75 & 525.00 & 45.21 & 317.03 & 1.32 & 2.39 & 55.2 \\
\hline 15 & Rice- Wheat & 6.5 & 0.18 & 1.56 & 468.00 & 40.25 & 290.32 & 1.34 & 2.38 & 56.3 \\
\hline 16 & Rice- Wheat & 6.5 & 0.19 & 2.14 & 640.00 & 56.20 & 280.33 & 1.30 & 2.37 & 54.8 \\
\hline 17 & Rice- Wheat-Rice & 6.4 & 0.20 & 2.44 & 740.00 & 56.32 & 390.65 & 1.38 & 2.31 & 59.7 \\
\hline 18 & Rice- Wheat & 6.4 & 0.31 & 2.74 & 824.00 & 57.21 & 110.45 & 1.39 & 2.34 & 59.4 \\
\hline 19 & Rice- Wheat & 6.3 & 0.29 & 2.63 & 787.00 & 37.12 & 105.02 & 1.34 & 2.36 & 56.7 \\
\hline 20 & Sugarcane & 6.3 & 0.34 & 2.57 & 768.00 & 31.31 & 299.05 & 1.38 & 2.39 & 57.7 \\
\hline 21 & Rice- Wheat & 6.3 & 0.40 & 1.49 & 450.00 & 37.32 & 105.06 & 1.32 & 2.38 & 55.4 \\
\hline 22 & Rice- Wheat & 6.3 & 0.34 & 2.34 & 693.00 & 31.63 & 299.03 & 1.31 & 2.37 & 55.6 \\
\hline 23 & Rice- Wheat & 6.3 & 0.28 & 2.08 & 618.00 & 40.25 & 230.03 & 1.38 & 2.39 & 57.7 \\
\hline 24 & Rice- Wheat-Rice & 6.6 & 0.19 & 1.66 & 496.00 & 36.32 & 120.05 & 1.39 & 2.31 & 60.1 \\
\hline
\end{tabular}




\begin{tabular}{|c|c|c|c|c|c|c|c|c|c|c|}
\hline 25 & Rice- Wheat & 6.5 & 0.20 & 2.71 & 825.00 & 36.32 & 240.10 & 1.38 & 2.34 & 58.9 \\
\hline 26 & Sugarcane & 6.5 & 0.24 & 1.81 & 535.00 & 51.36 & 290.20 & 1.38 & 2.35 & 58.7 \\
\hline 27 & Rice- Wheat & 6.4 & 0.26 & 2.32 & 693.00 & 56.23 & 320.30 & 1.35 & 2.26 & 59.7 \\
\hline 28 & Rice- Wheat & 6.5 & 0.31 & 1.51 & 452.00 & 40.12 & 160.01 & 1.36 & 2.38 & 57.1 \\
\hline 29 & Rice- Wheat & 6.0 & 0.32 & 2.70 & 820.00 & 40.21 & 140.05 & 1.32 & 2.39 & 55.2 \\
\hline 30 & Rice- Wheat & 6.5 & 0.37 & 2.08 & 618.00 & 42.21 & 310.61 & 1.31 & 2.37 & 55.2 \\
\hline 31 & Rice- Wheat & 6.6 & 0.38 & 1.50 & 450.00 & 20.32 & 160.00 & 1.32 & 2.38 & 55.4 \\
\hline 32 & Rice- Wheat & 6.7 & 0.29 & 1.40 & 430.00 & 23.25 & 105.21 & 1.33 & 2.39 & 55.6 \\
\hline 33 & Rice- Wheat & 6.6 & 0.34 & 1.50 & 450.00 & 18.50 & 152.03 & 1.32 & 2.24 & 58.9 \\
\hline 34 & Rice- Wheat & 6.7 & 0.36 & 2.09 & 618.00 & 36.63 & 231.03 & 1.35 & 2.40 & 60.2 \\
\hline 35 & Rice- Wheat & 6.4 & 0.40 & 1.81 & 543.00 & 36.36 & 112.62 & 1.36 & 2.41 & 56.4 \\
\hline 36 & Sugarcane & 6.7 & 0.35 & 1.66 & 487.00 & 37.36 & 190.32 & 1.39 & 2.28 & 60.9 \\
\hline 37 & Sugarcane & 6.8 & 0.26 & 1.75 & 525.00 & 31.56 & 125.32 & 1.38 & 2.37 & 58.2 \\
\hline 38 & Sugarcane & 6.8 & 0.19 & 1.59 & 470.00 & 25.65 & 131.35 & 1.33 & 2.37 & 56.1 \\
\hline 39 & Rice- Wheat & 6.7 & 0.18 & 1.62 & 487.00 & 28.35 & 190.36 & 1.38 & 2.39 & 57.7 \\
\hline 40 & Rice- Wheat & 6.7 & 0.24 & 1.43 & 430.00 & 29.32 & 131.39 & 1.37 & 2.28 & 60.0 \\
\hline 41 & Rice- Wheat-rice & 6.8 & 0.26 & 1.53 & 460.00 & 30.53 & 280.14 & 1.39 & 2.35 & 59.1 \\
\hline 42 & Rice- Potato & 6.8 & 0.19 & 2.80 & 843.00 & 25.36 & 339.45 & 1.35 & 2.27 & 59.4 \\
\hline 43 & Rice-pea & 6.8 & 0.21 & 2.24 & 675.00 & 20.56 & 131.12 & 1.38 & 2.39 & 57.7 \\
\hline 44 & Rice- Wheat & 6.8 & 0.23 & 2.11 & 637.00 & 24.36 & 113.12 & 1.34 & 2.27 & 59.0 \\
\hline 45 & Sugarcane & 6.7 & 0.35 & 2.77 & 825.00 & 32.23 & 155.13 & 1.36 & 2.34 & 58.1 \\
\hline 46 & Sugarcane & 6.7 & 0.40 & 1.30 & 392.00 & 28.32 & 119.13 & 1.39 & 2.35 & 59.1 \\
\hline 47 & Sugarcane & 6.8 & 0.31 & 2.71 & 821.00 & 32.32 & 125.15 & 1.33 & 2.26 & 58.8 \\
\hline 48 & Rice- Wheat & 6.7 & 0.35 & 1.81 & 543.00 & 31.23 & 428.16 & 1.32 & 2.35 & 56.1 \\
\hline 49 & Rice- Wheat & 6.7 & 0.24 & 2.56 & 768.00 & 30.33 & 131.14 & 1.31 & 2.36 & 55.5 \\
\hline 50 & Rice- Wheat & 6.8 & 0.31 & 1.35 & 393.00 & 25.00 & 167.13 & 1.35 & 2.34 & 57.6 \\
\hline 51 & Rice- Wheat-Rice & 6.8 & 0.24 & 1.17 & 355.00 & 28.21 & 161.21 & 1.36 & 2.28 & 59.6 \\
\hline 52 & Rice- Wheat-Rice & 6.8 & 0.40 & 1.81 & 543.00 & 29.00 & 220.25 & 1.39 & 2.39 & 58.1 \\
\hline 53 & Rice- Wheat-Rice & 6.8 & 0.31 & 1.32 & 393.00 & 30.00 & 226.36 & 1.35 & 2.38 & 56.7 \\
\hline 54 & Rice- Potato & 6.8 & 0.18 & 1.21 & 365.00 & 28.00 & 232.32 & 1.31 & 2.34 & 55.9 \\
\hline 55 & Sugarcane & 6.8 & 0.17 & 2.41 & 718.00 & 27.32 & 125.32 & 1.34 & 2.31 & 58.0 \\
\hline 56 & Sugarcane & 6.8 & 0.18 & 2.65 & 787.00 & 24.00 & 127.32 & 1.32 & 2.35 & 56.1 \\
\hline 57 & Rice- Wheat-Rice & 6.7 & 0.19 & 1.47 & 440.00 & 34.00 & 129.32 & 1.36 & 2.36 & 57.6 \\
\hline 58 & Rice- Wheat-Rice & 6.6 & 0.21 & 1.17 & 355.00 & 26.00 & 125.36 & 1.33 & 2.39 & 55.6 \\
\hline 59 & Sugarcane & 6.6 & 0.23 & 1.71 & 515.00 & 26.32 & 131.15 & 1.37 & 2.28 & 60.0 \\
\hline 60 & Rice- Wheat-Rice & 6.7 & 0.25 & 1.05 & 312.00 & 28.33 & 149.25 & 1.39 & 2.35 & 59.1 \\
\hline 61 & Rice- Wheat-Rice & 6.7 & 0.30 & 2.71 & 821.00 & 29.00 & 101.32 & 1.36 & 2.34 & 58.1 \\
\hline 62 & Sugarcane & 6.7 & 0.40 & 0.96 & 290.00 & 20.13 & 125.32 & 1.33 & 2.25 & 59.1 \\
\hline 63 & Sugarcane & 6.8 & 0.29 & 1.51 & 452.00 & 25.63 & 320.32 & 1.32 & 2.31 & 57.1 \\
\hline 64 & Sugarcane & 6.8 & 0.31 & 2.18 & 640.00 & 32.32 & 370.25 & 1.35 & 2.29 & 58.9 \\
\hline 65 & Rice-Wheat & 6.8 & 0.35 & 1.11 & 337.00 & 25.13 & 154.25 & 1.38 & 2.28 & 60.5 \\
\hline 66 & Rice- Wheat & 6.8 & 0.31 & 1.18 & 350.00 & 29.00 & 171.24 & 1.39 & 2.34 & 59.4 \\
\hline 67 & Rice- Wheat-Rice & 6.8 & 0.34 & 2.32 & 693.00 & 30.32 & 113.21 & 1.37 & 2.35 & 58.2 \\
\hline
\end{tabular}

$\mathrm{BD}=$ Bulk Density, $\mathrm{PD}=$ Particle density, $\mathrm{OC}=$ Organic carbon, $\mathrm{Av}=$ Available, and $\mathrm{EC}=$ Electrical conductivity. 
Table.2 Physico-chemical properties soils of Kanchanpur, district, Nepal

\begin{tabular}{|l|c|c|c|c|}
\hline Soil characteristics & Range & Mean & S.D. & C.V. (\%) \\
\hline pH(1:2.5) & $5.5-6.8$ & 7.24 & 0.32 & 5.67 \\
\hline E.C. $\left(\mathrm{dSm}^{-1}\right)$ & $0.16-0.40$ & 0.22 & 0.11 & 59.34 \\
\hline O.C. $(\%)$ & $0.95-4.20$ & 0.55 & 0.13 & 23.00 \\
\hline B.D. $\left(\mathrm{g} \mathrm{cm}^{-3}\right)$ & $1.32-1.42$ & 1.38 & 0.01 & 2.15 \\
\hline P.D. $\left(\mathrm{g} \mathrm{cm}^{-3}\right)$ & $2.25-2.42$ & 2.35 & 0.04 & 2.09 \\
& & & & \\
\hline
\end{tabular}

Table.3 Status of available macronutrients viz. available N, P, and K in soils of Kanchanpur, district, Nepal

\begin{tabular}{|l|c|c|c|c|}
\hline Soil characteristics & Range & Mean & S.D. & C.V. \\
\hline Available N $\left(\mathrm{kg} \mathrm{ha}^{-1}\right)$ & $290-1218$ & 580.11 & 40.12 & 23.80 \\
\hline Available P $\left(\mathbf{k g ~ h a}^{-1}\right)$ & $18.5-90.5$ & 35.74 & 1.33 & 25.10 \\
\hline Available K $\left(\mathrm{kg} \mathrm{ha}^{-1}\right)$ & $101.3-428.1$ & 201.94 & 33.582 & 17.32 \\
\hline
\end{tabular}

Table.4 Classification OC\% and available Macro nutrients status content in soils of Kanchanpur, district, Nepal

\begin{tabular}{|c|c|c|c|c|c|c|c|}
\hline \multirow[t]{2}{*}{ S.No. } & \multirow[t]{2}{*}{ Elements } & $\begin{array}{l}\text { No. of } \\
\text { samples }\end{array}$ & $\begin{array}{l}\% \text { of } \\
\text { samples }\end{array}$ & $\begin{array}{l}\text { No. of } \\
\text { samples }\end{array}$ & $\begin{array}{l}\% \text { of } \\
\text { samples }\end{array}$ & $\begin{array}{l}\text { No. of } \\
\text { samples }\end{array}$ & $\begin{array}{l}\% \text { of } \\
\text { samples }\end{array}$ \\
\hline & & \multicolumn{2}{|c|}{ Low } & \multicolumn{2}{|c|}{ Medium } & \multicolumn{2}{|c|}{ High } \\
\hline 1 & $\mathrm{OC} \%$ & 0 & 0.00 & 0 & 0.00 & 67 & 100 \\
\hline 2 & $\mathrm{~N}$ & 0 & 0.00 & 37 & 55.22 & 30 & 54.88 \\
\hline 3 & $\mathrm{P}$ & 0 & 0.00 & 8 & 11.94 & 59 & 88.05 \\
\hline 4 & $\mathrm{~K}$ & 23 & 34.32 & 39 & 58.20 & 5 & 7.46 \\
\hline
\end{tabular}

Table.5 Rating limits for soil test values used in India (Muhret al., 1965)

\begin{tabular}{|l|c|c|c|}
\hline \multirow{2}{*}{ Nutrients } & \multicolumn{3}{|c|}{ Rating of the soil test values } \\
\cline { 2 - 4 } & Low & Medium & High \\
\hline Organic carbon $(\%)$ & $<0.5$ & $0.5-0.75$ & $>0.75$ \\
\hline Available $\mathrm{N}\left(\mathrm{kg} \mathrm{ha}^{-1}\right)$ & $<280$ & $280-560$ & $>560$ \\
\hline Available P $\left(\mathrm{kg} \mathrm{ha}^{-1}\right)$ & $<12.5$ & $12.5-25$ & $>25$ \\
\hline Available K $\left(\mathrm{kg} \mathrm{ha}^{-1}\right)$ & $<135$ & $135-335$ & $>335$ \\
& Deficient & Sufficient & \\
\hline
\end{tabular}


Table.6 Correlations between physic- chemical properties and available macro nutrients in the soil of Kanchanpur, district, Nepal

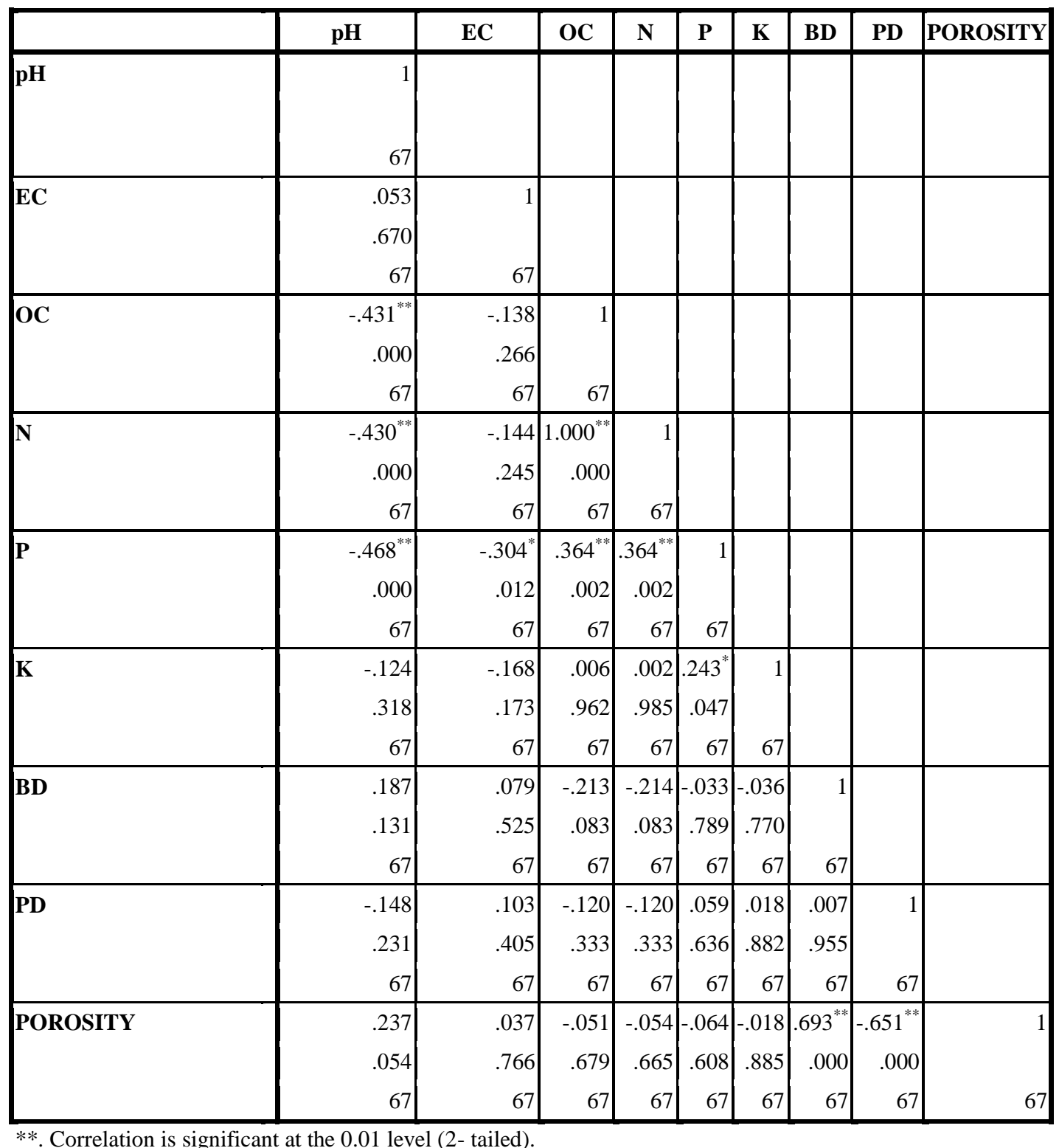

This may be due to phosphorus build up in soil because of high biomass in soil, or, phosphatic fertilizer application. These finding are in agreement with the result reported by Meena et $a l$. , in soil of Tonk district of Rajasthan. The potassium content in these soils was ranged from 101.3 to $428.1 \mathrm{~kg} / \mathrm{ha}$ with a mean value of $201.94 \mathrm{~kg} \mathrm{ha}^{-1}$ K. S.D. value 33.582 and C.V. value of $17.32 \%$. Out of 67 soil samples $38.32 \%$ soil samples were found low, $58.20 \%$ soil samples were found medium and $7.46 \%$ sample founded high in K content.

Correlation between physico-chemical properties and available macro nutrients in the soils of Kanchanpur, district, Nepal

Correlation between physico-chemical properties and available macro-nutrients in soils shows in table 6 . Since most of the soil 
Nitrogen is found in organic form, therefore, this relationship was observed. Available nitrogen is negatively $\left(-0.430^{* * *}\right)$ correlated with $\mathrm{pH}$, negatively (-0.144) correlated with EC, positively $(1.000 * *)$ correlated with OC, negatively $(-0.214)$ correlated with $\mathrm{BD}$ and positively $(0.120)$ correlated with $\mathrm{PD}$.

Available phosphorous is positively (0.468) correlated with $\mathrm{pH}$, positively $(0.304)$ correlated with EC, positively (0.364) correlated with OC, positively (0.033) correlated with $\mathrm{BD}$ and positively (0.059) correlated with PD. The relationship between available $\mathrm{P}$ and $\mathrm{C}$ level could not exhibit the concurrent results. Jatav and Mishra have also reported the similar results in soil of Mewar region of Rajasthan and Janjigar district of Chhattishgarh.

Available potassium is negatively $(-0.124)$ correlated with $\mathrm{pH}$, positively $(-0.168)$ correlated with EC, positively (0.006) correlated with OC, Negatively (0.036) correlated with $\mathrm{BD}$ and positively (0.018) correlated with PD.

It can be concluded that, the soil from Kanchanpur, district, Nepal is categorized under slightly acidic to moderately neutral in reaction, out of 67 soil samples 100\% were found High in organic carbon in the soils of studied area. $55.22 \%$ medium and $54.88 \%$ high in available nitrogen, available phosphorus found medium $11.94 \%$ to high $88.05 \%$ and available potassium $34.32 \%$ found in low, $58.20 \%$ found in medium and $7.46 \%$ found high range. Proper agriculture practices, intensive farming, forest biomass are responsible for maintaining soil fertility status of the study area. To overcome from the adverse effect of the chemical cultivation efforts should be made to exploit all the available resource of nutrients under the theme of integrated nutrient management (INM). Under this approach the best available option lies in the complimentary use of bio-fertilizers, organic manures in suitable combination of chemical fertilizers. 'Organic agriculture' system should be inoculated which begins to consider potential environmental and social impacts by eliminating the use of synthetic inputs such as synthetic fertilizers, pesticides etc. The camps, rallies and training programs for the farmers should be arranged for increasing awareness regarding the benefits of organic agriculture, bio-fertilizers etc. in crop production and thereby improving soil fertility and nutrients status.

\section{Acknowledgement}

The authors are highly grateful to Regional Soil testing laboratory Sundarpur Kanchanpur, for providing necessary facility to carry out this work and International Rice Research Institute Nepal, for their financial support, and also thankful to Institute of Agricultural Sciences, Banaras Hindu University Varanasi, India.

\section{References}

Babel, A.L. Available Micronutrient Status and their Relationship with Soil Properties.

Black, C.A. 1965. Soil Plant relationship $2^{\text {nd }}$ edition New York., Pub. USA, pp. 515516.

Chauhan, J.S. 2001. Fertility status of soils of Birla Panchayat Samiti of Jodhpur district Rajasthan, Master's thesis, MPUAT, Udaipur.

Chopra, S.L and Kanwar, J.S. 2005. Analytical Agricultural chemistry. Kalyani publishers, New Delhi.

Das, D.K. Role of soil information systems in sustainable use of land resources.

Deshmukh, K.K. 2012. Evaluation of soil fertility status from sangamner area, Ahmednagar District Maharastra, India. Rasayan J. Chem., 5: 398-406.

Fageria, V.D. 2001. Nutrient Interactions in Crop plants, J. Plant Nutri., 24(8): 12691290.

Gupta, S., Mallick, T., Datta, J.K. and Saha, R.N., Impact of opencast mining on the soil and plant communities of SonepurBajari opencast coal mine area, West Bengal, India. Vista in Geol., 5: 94-198.

Hanway, T.J. and Heidal, H. 1952. Soil analysis methods as used in Iowa State soil testing 
laboratory. Iowa Agri., 57: 1-31.

Indian Society of Soil Sci., 1999; 47: 584-610.

Jackson, M.L. 1973. Soil chemical analysis. Prentice Hall of India Pvt. Ltd., New Delhi.

Jatav, G.K. and Mishra, V.N. 2012. Evaluation of soil fertility status of available N, P and $\mathrm{K}$ in Kumar, inceptisol of Baloda block of Janjgir district of Chhattisgarh. $J$. Progressive Agri., 3(1): 28-32.

Lal, R. and Singh, B.R. Effect of soil degradation on crop productivity in East Africa.

Latha, K.R. and Singh, R. 2003. Effect of cropping systems and fertilizer levels on the nutrient uptake and yield by sorghum in rainfed vertisols. Indian J. Agri. Res., 37: 209-213.

Mali, V.S., Zende, N.A. and Verma, U.K. Correlation between soil physic-chemical propertiesand available micronutrients in salt affected soils symposium no. 33 paper no. 2220 presentation.

Mathur, G.M., Deo, R. and Yadav, B.S. 2006. Status of zinc in irrigated North-West Plain soils of Rajasthan. J. Indian Society of Soil Sci., 54(3): 359-361.

Meena, H.B., Sharma, P.R. and Rawat, U.S. 2006. Status of macro-micronutrients in some soils of Tonk district of Rajasthan. J. Indian Society of Soil Sci., 54: 508-512.

Muhur, G.R., Datta, N.P., Subramany, N.S., Dever, F., Lecy, V.K. and Donahue, R.R. 2011. Soil testing in India, USDA, publication, 1965; 120.of Jhunjhunu tehsil, district Jhunjhunu, Rajasthan, India. J. Agri. Sci., 3(2): 97-106.

Olsen, S.R., Cole, C.V., Watanbe, F.S. and Dean, L.A., Estimation of available phosphorus in soilby extracting with sodium bicarbonate. U.S.A. Circ. 939. (c.f. methods of soil analysis, part 2. Ed. C. A. Black, American Society of Agronomy, Madison, Wisconsin.

Ramana, Singh Y.V., Jat L.K., Meena Santosh K., Singh Lakhapati, Jatav, H.S. and Paul Alpana. 2015. Available Macro Nutrient Status and their Relationship with Soil phsico- chemical properties of Sri Ganganagar District of Rajasthan, India. J. Pure and Appl. Microbiol., 9(4): p. 2887-2894.

Sharma, R.P., Yadava, R.B., Lama, T.D., Bahadur, A. and Singh, K.P. 2013. Status of secondary nutrientsvis-a-vis soil sitecharacteristics of vegetable growing soils of Varanasi. Vegetable Sci., 40(1): 65-68.

Singh, D.P. and Rathore, M.S. 2013. Available nutrient status and their relationship with soil properties of Aravalli mountain ranges and Malwa Plateau of Pratapgarh, Rajasthan, India. African J. Agri. Res., 8(41): 5096-5103.

Singh, R.P. and Mishra S.K. 2013. Available macro nutrients $(\mathrm{N}, \mathrm{P}, \mathrm{K}$, And $\mathrm{S}$ ) in the soils of Chiraigaon block of districts Varanasi (U.P) in Relation to soil characteristics, Indian J. Scientific Res., 3(1): 97-100.

Soils of arid tract of Punjab, Indian. 2005. $J$. Agri. Biol., 7(2): 370-372.

Subbiah, B.V. and Asija G.L. 1956. A rapid procedure for estimation of available nitrogen in soil. Curr. Sci., 25: 259-260.

Sustainable Agriculture, 1998; 13(1): 15-41.

Yadav, B.K. 2011. Micronutrient status of soils under legume crops in arid region of Western Rajasthan, India. Academic $J$. Plant Sci., 4(3): 94-97.

\section{How to cite this article:}

Khan, A.I., N.L. Uranw, R.N. Yadav, Y.V. Singh, Durgawati Patel and Renu Yadav. 2017. Evaluation of Soil Fertility Status from Kanchanpur district, Far-Western Development Region of Nepal. Int.J.Curr.Microbiol.App.Sci. 6(3): 961-968. doi: https://doi.org/10.20546/ijcmas.2017.603.114 